\title{
EFEKTIVITAS SATELIT RNA YANG BERASOSIASI DENGAN CUCUMBER MOSAIC VIRUS (CARNA-5) UNTUK MENGENDALIKAN PENYAKIT VIRUS PADA TANAMAN TOMAT
}

\author{
Hasriadi Mat Akin, Muhammad Nurdin, Patrisius Binsar Simamora \& Marlaba Sitorus \\ Bidang Proteksi Tanaman Jurusan Agroteknologi, Fakultas Pertanian, Universitas Lampung \\ Jl. Prof. Sumantri Brojonegoro No. 1 Bandar Lampung 35145 \\ E-mail: hasriadi_akin@unila.ac.id
}

\begin{abstract}
Effectivity of Cucumber mosaic virus associated satellite RNA to control viral disease on tomato plants. Two strains of CMV associated satellite RNA (CARNA 5.1 and CARNA 5.2) were evaluated to control severe strain of Cucumber mosaic virus (CMV-G), Tobacco mosaic virus (TMV), and Potato virus $\mathrm{Y}$ (PVY) on tomato plants. Tomato plants were mechanically inoculated with CARNA 5.1 and CARNA 5.2 to protect the plants from super infection of CMV-G, TMV, and PVY. The result revealed that inoculation of CARNA 5.1 and CARNA 5.2 to tomato plants effectively controlled the plants from CMV-G super infection. The effectiveness of CARNA 5.1 and CARNA 5.2 to unrelated virus, TMV and PVY, was evaluated in this experiment. The result showed that CARNA 5.1 and CARNA 5.2 inhibited TMV and PVY infection. CMV-G super infection on protected tomato plants showed mild disease symptoms, significant redution of plant growth, height, and yield; however, nonprotected plants showed severe disease symptoms and significant inhibition of plant growth and tomato yield.
\end{abstract}

Key words: cucumber mosaic virus, satelit RNA, CARNA 5, tomato

\begin{abstract}
ABSTRAK
Efektivitas satelit RNA yang berasosiasi dengan Cucumber mosaic virus (CARNA-5) untuk mengendalikan virus pada tanaman tomat. Dua strain CMV yang berasosiasi dengan satelit RNA (CARNA 5.1 dan CARNA 5.2) dievaluasi untuk mengendalikan strain ganas Cucumber mosaic virus (CMV-G), Tobacco mosaic virus (TMV), dan Potato virus Y (PVY) pada tanaman tomat. Tanaman tomat diinokulasi secara mekanik menggunakan CARNA 5.1 dan CARNA 5.2 untuk melindungi tanaman dari superinfeksi CMV-G, TMV, dan PVY. Hasil penelitian menunjukkan bahwa inokulasi CARNA 5.1 dan CARNA5.2 pada tanaman tomat efektif melindungi tanaman dari superinfeksi CMV-G. Kefektivan CARNA 5.1 dan CARNA 5.2 terhadap virus lainnya yaitu TMV dan PVY telah diuji pada penelitian ini. Hasil penelitian menunjukkan bahwa CARNA 5.1 dan CARNA 5.2 dapat menghambat infeksi TMV dan PVY. Superinfeksi CMV-G pada tomat yang telah divaksin CARNA 5.1 dan CARNA 5.2 secara signifikan menunjukkan gejala penyakit yang lebih ringan dan tidak menghambat pertumbuhan serta tidak menurunkan tinggi tanaman dan hasil, sedangkan tanaman tomat yang tidak divaksin menunjukkan gelaja penyakit yang parah dan secara nyata menghambat dan menurunkan produksi tanaman tomat.
\end{abstract}

Kata kunci: cucumber mosaic virus, satelit RNA, CARNA 5, tomat

\section{PENDAHULUAN}

Salah satu hambatan dalam budidaya tanaman tomat adalah penyakit yang disebabkan oleh virus. Telah diketahui 18 jenis virus yang secara alamiah dapat menyerang tanaman tomat. Diantara virus-virus yang dapat menyerang tanaman tomat, Cucumber mosaic virus (CMV) merupakan virus yang paling merugikan (Crescenzi et al., 1993). Pada beberapa lokasi sentra produksi tomat di Indonesia atau di belahan dunia lain, penyakit yang ditimbulkan oleh CMV telah menimbulkan kerugian yang cukup besar (Alonso-Prados et al., 1997) terutama oleh isolat-isolat nekrogenik yang dapat mengakibatkan bercak nekrotik pada buah dan kematian tanaman tomat (Crescenzi et al., 1993; Jorda et al., 1992).

Di Indonesia, virus yang banyak menyerang tanaman tomat adalah Tobacco mosaic virus (TMV), Potato virus Y (PVY) dan Cucumber mosaic virus (CMV). TMV dan CMV secara bersama-sama dapat mengurangi produksi sampai $50 \%$ tergantung umur tanaman saat terjadi infeksi dan varietas tomat (Sutarya, 1989). Sampai saat ini beberapa usaha pengendalian telah dilakukan, namun belum ada metode yang dapat 
memberikan hasil yang efektif untuk mengendalikan CMV di lapangan (Gallitelli, 1998; Jorda et al., 1992; Summers et al., 1995).

Beberapa faktor yang menyebabkan sulitnya mengendalian penyakit tanaman tomat yang disebabkan oleh CMV antara lain: (a) tanaman yang terlanjur terinfeksi CMV tidak dapat disembuhkan dan tanaman ini dapat menjadi sumber inokulum untuk tanaman di sekitarnya; (b) CMV mempunyai kisaran inang yang sangat luas termasuk beberapa tumbuhan liar (Gafny et al., 1996; Palukaitis et al., 1992) yang dapat menjadi inang perantara dan dapat menjadi sumber inokulum setiap saat; (c) CMV dapat ditularkan oleh banyak spesies kutu daun dengan efektivitas penularan tinggi (dapat ditularkan dengan hanya satu ekor serangga) (Gallitelli et al., 1995; Martin et al., 1997; Palukaitis et al., 1992; Perry et al., 1994; Perry et al., 1995); (d) sanitasi dengan memusnahkan tanaman sakit di lapang belum memberi jaminan karena sumber inokulum pada tanaman inang antara dan vektor berlimpah di luar pertanaman tomat; (e) pengendalian vektor sebagai serangga hama dengan senyawa kimia yang harus mempertimbangkan kelestarian lingkungan belum dapat diharapkan menekan populasi vektor pada tingkat yang aman untuk tidak terjadi penularan (Herdt \& Steiner, 1995); dan (f) sampai sekarang belum tersedia varietas tomat yang toleran atau tahan terhadap CMV.

Berdasarkan permasalahan di atas maka pengendalian yang paling menjanjikan adalah pengendalian hayati dengan agen biokontrol menggunakan satelit RNA yang telah ada secara alami. Penggunaan CARNA-5 sebagai vaksin merupakan altenatif yang diharapkan dapat mengatasi permasalahan tersebut. Vaksin CARNA-5 selain aman terhadap lingkungan dan konsumen juga murah dan mudah diaplikasikan pada tingkat petani. Satelit RNA adalah molekul RNA yang berukuran antara 300-1500 nukleotida merupakan parasit molekuler dari virus tumbuhan yang dapat menghambat proses replikasi virus dalam sel tanaman inang (Hu et al., 2009).

Hasil penelitian sebelumnya menunjukkan bahwa beberapa strain CMV yang mengandung satelit RNA dan dapat digunakan sebagai vaksin penginduksi ketahanan tanaman cabai terhadap superinfeksi strain ganas CMV (Akin, 2005). Superinfeksi adalah infeksi virus pada tanaman yang sudah terinfeksi oleh virus lain. Strain lemah CMV-LW3 (CARNA-5.1) tidak menimbulkan reaksi sinergi ataupun antagonis dengan virus lain dan tidak menimbulkan penurunan hasil tanaman cabai (Zulistiyorini, 2005; Saputri, 2005; Akin, 2005; Wagiyanto, 2005). CARNA-5.1 ini diperoleh dengan cara melemahkan CMV isolat Liwa dari tanaman cabai petani yang dilakukan menggunakan metode penginokulasian CMV sebanyak 9 kali berturut-turut pada tanaman tembakau (N. tabaccum). CMV-2 (CARNA-5.2) merupakan CMV yang mengandung satelit RNA yang telah digunakan untuk mengendalikan CMV pada tanaman cabai. CARNA-5.2 dalam penelitian ini diperoleh dari Balai Penelitian Tanaman Sayur-sayuran Lembang. Penelitian ini bertujuan (1) mengetahui efektivitas dua strain lemah CARNA-5.1 dan CARNA-5.2 untuk mengendalikan penyakit virus pada tanaman tomat yang disebabkan oleh strain ganas CMV-G, dan (2) mengetahui pengaruh vaksinasi CARNA-5.1 dan CARNA-5.2 terhadap virus lain yang menyerang tomat TMV dan PVY.

\section{METODE PENELITIAN}

Tempat dan Waktu. Penelitian ini dilaksanakan di rumah plastik kebun percobaan Universitas Lampung. Penelitian ini dilakukan mulai Juni 2008-Juni 2009. Penelitian terdiri atas dua percobaan dalam skala rumah plastik, yaitu (1) Efektivitas proteksi dua vaksin CARNA5.1 dan CARNA-5.2 dalam melindungi tanaman tomat dari infeksi strain ganas CMV; dan (2) Pengaruh vaksinasi CARNA-5.1 dan CARNA-5.2 terhadap infeksi virus lain yang menyerang tomat (TMV dan PVY).

Efektivitas Proteksi Dua Vaksin CARNA-5.1 dan CARNA-5.2 dalam Melindungi Tanaman Tomat terhadap Infeksi Strain Ganas CMV. Perlakuan dalam percobaan ini disusun dalam rancangan acak lengkap (RAL) dengan 6 perlakuan dan 3 ulangan. Masing-masing perlakuan diatur sebagai berikut: (1) Tanaman tomat yang berumur 10 hari setelah tanam (hst) divaksinasi CARNA-5.1. Vaksinasi dilakukan dengan cara menginokulasikan CARNA-5.1 pada tanaman tomat, (2) Tanaman tomat yang berumur 10 hst divaksinasi CARNA-5.2, (3) Tanaman tomat yang berumur 10 hst diinokulasi dengan strain ganas CMVG, (4) Tanaman tomat yang berumur 10 hst divaksinasi CARNA-5.1, kemudian pada 30 hst diinokulasi dengan strain ganas CMV-G, (5) Tanaman tomat yang berumur 10 hst divaksinasi CARNA-5.2, kemudian pada $30 \mathrm{hst}$ diinokulasi dengan strain ganas CMV-G, (6) Tanaman tomat tidak diberi perlakuan sebagai kontrol. Data hasil pengamatan dianalisis dengan analisis ragam dan dilanjutkan dengan uji nilai tengah menggunakan uji beda nyata jujur (BNJ) pada taraf 0,05 . 
Pengaruh Vaksinasi CARNA-5.1 dan CARNA-5.2 terhadap Infeksi Virus Lain yang Menyerang Tomat (TMV dan PVY) Perlakuan dalam percobaan ini disusun dalam rancangan acak lengkap (RAL) dengan 11 perlakuan dan 3 ulangan. Masing-masing perlakuan diatur sebagai berikut: (1) Tanaman tomat yang berumur 10 hari setelah tanam (hst) divaksinasi CARNA-5.1. Vaksinasi dilakukan dengan cara menginokulasikan CARNA-5.1 pada tanaman tomat, (2) Tanaman tomat yang berumur 10 hst divaksinasi CARNA-5.2, (3) Tanaman tomat yang berumur $10 \mathrm{hst}$ diinokulasi dengan PVY, (4) Tanaman tomat yang berumur 10 hst diinokulasi dengan TMV, (5) Tanaman tomat yang berumur 10 hst divaksinasi CARNA-5.1, kemudian pada 30 hst diinokulasi dengan PVY, (6) Tanaman tomat yang berumur $10 \mathrm{hst}$ divaksinasi CARNA-5.2, kemudian pada 30 hst diinokulasi dengan TMV, (7) Tanaman tomat yang berumur $10 \mathrm{hst}$ divaksinasi CARNA-5.1, kemudian pada $30 \mathrm{hst}$ diinokulasi dengan TMV, (8) Tanaman tomat yang berumur 10 hst divaksinasi CARNA-5.2, kemudian pada 30 hst diinokulasi dengan PVY, (9) Tanaman tomat yang berumur 10 hst divaksinasi CARNA-5.1, kemudian pada 30 hst diinokulasi dengan PVY dan TMV, (10) Tanaman tomat yang berumur 10 hst divaksinasi CARNA-5.2, kemudian pada 30 hst diinokulasi dengan PVY dan TMV, (11) Tanaman tomat tidak diberi perlakuan sebagai kontrol. Data hasil pengamatan dianalisis dengan analisis ragam dan dilanjutkan dengan uji nilai tengah menggunakan uji beda nyata jujur (BNJ) pada taraf 0,05 .

Penyiapan Tanaman. Benih tanaman tomat varietas Ratna disemai dalam nampan dan setelah berumur 2 minggu dipindahkan ke dalam polibeg yang berisi $10 \mathrm{~kg}$ media tumbuh yang terdiri atas campuran tanah, pupuk kandang, dan pasir dengan perbandingan 2:1:1. Polibeg yang telah ditanami bibit tomat disusun sesuai dengan rancangan yang digunakan dalam rumah plastik kedap serangga. Masing-masing ulangan terdiri atas 5 polibeg dan setiap polibeg ditanami satu tanaman tomat.

Inokulasi Mekanik. Metode inokulasi mekanik dilakukan sebagai berikut 1 gr daun tomat sumber isolat CMV digerus dalam nitrogen cair dengan mortar dan pestel steril sampai berbentuk tepung halus. Mortar diletakkan di atas es, kemudian ditambahkan $5 \mathrm{ml}$ bufer potasium fosfat (100 mM, pH 7.2) yang mengandung $0,02 \%$ 2-mercaptoethanol. Suspensi yang diperoleh segera dioleskan dengan kapas steril pada permukaan daun tomat yang terlebih dahulu ditaburi karburondum.
Pengamatan. Pengamatan dilakukan untuk peubah keparahan penyakit, jumlah dan bobot buah per tanaman, tinggi tanaman. Pengamatan keparahan penyakit dilakukan setiap minggu dimulai dari dua minggu setelah inokulasi vaksin CARNA-5. Intensitas penyakit dihitung berdasarkan rumus:

$$
K P=\frac{\sum(n \times v)}{N \times V} \times 100 \%
$$

dengan:

$\mathrm{KP}=$ keparahan penyakit;

$\mathrm{n}=$ jumlah tanaman pada setiap kategori gejala;

$\mathrm{v}=$ nilai skor pada setiap kategori gejala;

$\mathrm{N}=$ jumlah total tanaman yang diamati;

$\mathrm{V}=$ Nilai skor tertinggi dari kategori gejala.

Skor v ditentukan dengan kategori sebagai berikut:

$0=$ tidak ada gejala;

$1=$ gejala mosaik atau belang ringan, lesio lokal atau tidak ada penyebaran sistemik;

2 = gejala mosaik atau belang sedang;

$3=$ gejala mosaik atau belang berat tanpa penciutan atau kelainan bentuk (malformation) daun;

$4=$ gejala mosaik atau belang sangat berat dengan penciutan atau kelainan bentuk; daun yang parah (shoestring), kerdil dan mati;

$5=$ gejala mosaik yang berat, nekrosis batang, dan tanaman mati.

\section{HASIL DAN PEMBAHASAN}

Efektivitas Proteksi Silang Dua Vaksin CARNA5.1 dan CARNA-5.2 terhadap Infeksi Strain Ganas CMV. Hasil penelitian menunjukkan bahwa berdasarkan keparahan penyakit, vaksinasi CARNA 5.1 yang didapat secara alamiah dan CARNA 5.2 yang diperoleh secara buatan dengan metode inokulasi sebanyak 9 kali berturutturut pada tanaman tembakau (N. tabaccum) (CARNA 5.1) dapat melindungi tanaman dari superinfeksi strain ganas CMV (CMV-G). Proteksi tanaman tomat terhadap strain ganas dimulai pada pengamatan $2 \mathrm{msi}$ dan 3 msi (Tabel 1). Hasil penelitian ini menunjukkan bahwa antara CARNA 5.2 yang merupakan strain lemah alami yang diperoleh dari Balai Penelitian. Tanaman Sayur-sayuran Lembang dan CARNA 5.1 strain yang dilemahkan tidak berbeda efektivitasnya dalam melindungi tanaman tomat dari superinfeksi CMV-G.

Proteksi tanaman tomat dari infeksi strain ganas juga ditunjukkan oleh tinggi tanaman tomat. Tanaman 
Tabel 1. Keparahan penyakit pada tanaman yang divaksinasi dengan CARNA 5.1 dan CARNA 5.2

\begin{tabular}{lccc}
\hline \multirow{2}{*}{ Perlakuan } & \multicolumn{3}{c}{ Keparahan penyakit (\%) } \\
\cline { 2 - 4 } & $1 \mathrm{msi}$ & $2 \mathrm{msi}$ & $3 \mathrm{msi}$ \\
\hline & $4,67 \mathrm{a}$ & $9,00 \mathrm{a}$ & $15,67 \mathrm{a}$ \\
Kontrol & $35,00 \mathrm{~b}$ & $43,00 \mathrm{~b}$ & $53,00 \mathrm{~b}$ \\
Inokulasi dengan strain ganas CMV-G & $24,00 \mathrm{ab}$ & $34,33 \mathrm{ab}$ & $38,67 \mathrm{ab}$ \\
Vaksinasi CARNA-5.1 & $23,00 \mathrm{ab}$ & $32,67 \mathrm{ab}$ & $43,33 \mathrm{ab}$ \\
Vaksinasi CARNA-5.2 & $27,00 \mathrm{~b}$ & $28,33 \mathrm{ab}$ & $39,00 \mathrm{ab}$ \\
Vaksinasi CARNA-5.1, dilanjutkan dengan inokulasi & & & \\
strain ganas CMV-G pada 30 hst & $27,67 \mathrm{~b}$ & $33,33 \mathrm{ab}$ & $42,00 \mathrm{ab}$ \\
Vaksinasi CARNA-5.2 dilanjutkan dengan inokulasi & & & \\
strain ganas CMV-G pada 30 hst & &
\end{tabular}

Angka yang diikuti dengan huruf yang sama pada kolom yang sama tidak berbeda nyata menurut uji BNJ $(\mathrm{P}>0,05)$

yang divaksinasi dengan CARNA 5.2 tidak mengalami hambatan pertumbuhan tinggi tanaman atau sama dengan tanaman kontrol. Hal itu juga ditunjukkan oleh tanaman yang divaksinasi CARNA 5.2 tanpa diikuti oleh inokulasi strain ganas CMV. Sebaliknya tanaman yang divaksinasi dengan CARNA 5.1 mengalami hambatan pertumbuhan tinggi tanaman (Gambar 1).

Bobot buah tomat yang dihasilkan oleh tanaman yang telah diproteksi dengan CARNA 5.1 dan CARNA
5.2 juga relatif lebih besar bila dibandingkan dengan bobot buah tanaman yang tidak divaksinasi. Hal ini menunjukkan bahwa vaksin CARNA 5.1 dan CARNA 5.2 efektif memproteksi tanaman tomat dari infeksi strain ganas CMV (Gambar 2). Mekanisme fisiologi infeksi virus pada tanaman adalah terjadinya kompetisi penggunaan metabolit tanaman seperti asam nukleat dan asam amino yang berdapak kepada berkurangnya ketersediaan metabolit yang diperlukan untuk keperluan

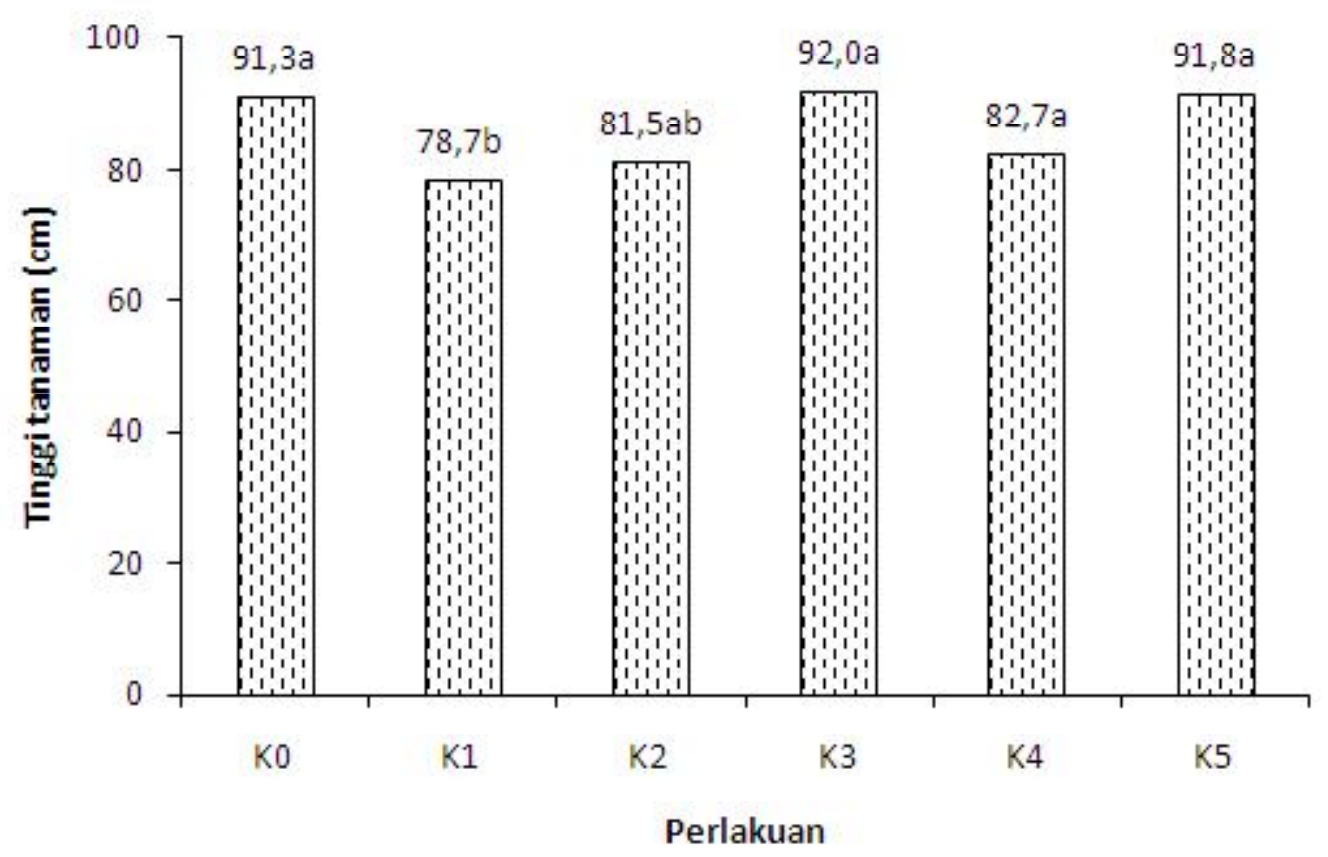

Gambar 1. Rerata tinggi tanaman tomat dari masing-masing perlakuan.K0 = Kontrol (tanaman sehat), $\mathrm{K} 1=$ inokulasi starin ganas (CMV-G), K2 = tanaman divaksinasi dengan Carna 5.1, K3 = tanaman divaksinasi dengan Carna 5.2, K4 = tanaman divaksin dengan CARNA 5.1 sebelum inokulasi CMV-G, dan K5 = tanaman divaksin dengan CARNA 5.2 sebelum inokulasi CMV-G. 


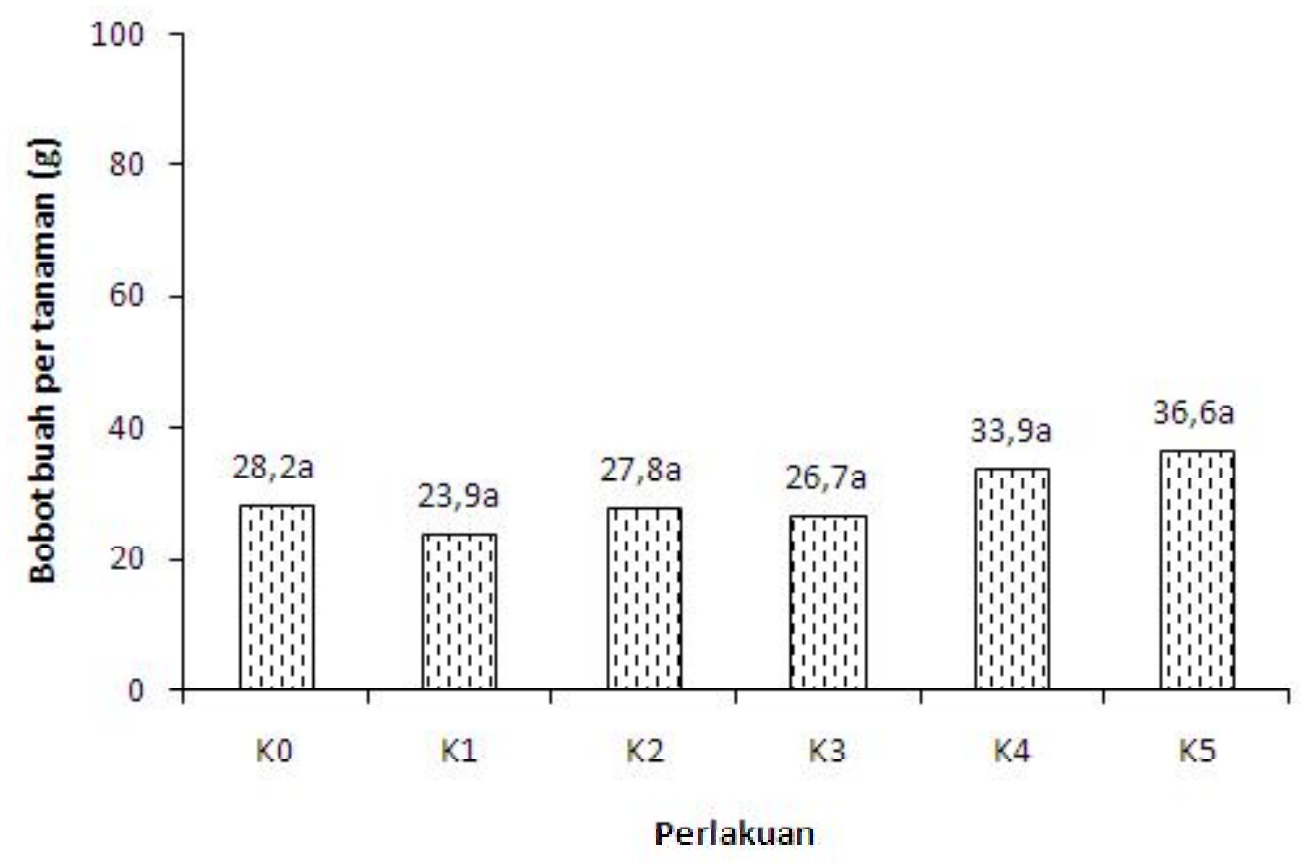

Gambar 2. Rerata bobot buah tomat per tanaman pada masing-masing perlakuan. $\mathrm{K} 0=$ Kontrol (tanaman sehat), $\mathrm{K} 1$ = inokulasi starin ganas $(\mathrm{CMV}-\mathrm{G}), \mathrm{K} 2$ = tanaman divaksinasi dengan Carna 5.1, $\mathrm{K} 3$ = tanaman divaksinasi dengan Carna 5.2, $\mathrm{K} 4$ = tanaman divaksin dengan CARNA 5.1 sebelum inokulasi CMV-G, dan $\mathrm{K} 5$ = tanaman divaksin dengan CARNA 5.2 sebelum inokulasi CMV-G).

pertumbuhnan vegetatif dan generatif tanaman inang (Akin, 2006).

Pemanfaatan satelit (sat) RNA CMV untuk mengendalikan CMV telah berhasil dilakukan untuk strain CMV yang menyerang tanaman cabai. Uhan dan Duriat (1995) melaporkan penggunaan vaksin CARNA5.2 (satRNA) yang dapat mempertahankan hasil cabai dua setengah kali tanaman cabai yang tidak divaksin. Akin (2005) melaporkan bahwa strain lemah CMV yang berasosiasi dengan satelit RNA (CARNA 5.1) dapat memproteksi tanaman cabai dari serangan strain ganas CMV. Ia juga melaporkan bahwa infeksi strain lemah CMV yang berasosiasi dengan satelit RNA tidak menurunkan kuantitas dan kualitas hasil tanaman cabai.

Kedua vaksin CARNA 5.1 dan CARNA 5.2 dapat memproteksi tanaman tomat dari superinfeksi strain ganas CMV-G. Hal itu terlihat pada produksi tomat pada tanaman yang divaksin lebih tinggi dari tanaman lain. Walaupun keparahan penyakit pada tanaman yang divaksin relatif tinggi, namun bobot buah yang dihasilkan lebih tinggi dari tanaman yang terinfeksi strain ganas. Fenomena tersebut mengindikasikan bahwa tipe ketahanan tanaman tomat yang telah divaksinasi tergolong ke dalam toleran.
Pengaruh Vaksinasi CARNA-5.1 dan 5.2 terhadap Infeksi Virus Lain yang Menyerang Tomat (TMV dan PVY). Hasil penelitian pada tahap ini menunjukkan bahwa berdasarkan keparahan penyakit pada $4 \mathrm{msi}$ vaksinasi CARNA 5.1 maupun CARNA 5.2 tidak efektif melindungi tanaman tomat dari superinfeksi virus lain yang menyerang tanaman tomat, seperti PVY dan TMV baik infeksi tunggal maupun infeksi ganda yang ditunjukkan oleh keparahan penyakit yang relatif tinggi dan tidak berbeda antara tanaman yang divaksinasi dan tidak divaksinasi (Tabel 2).

Hasil pengamatan bobot buah tanaman tomat yang divaksinasi menunjukkan bahwa tanaman yang divaksinasi menghasilkan buah yang lebih tinggi bila dibandingkan dengan tanaman yang tidak divaksinasi walaupun keparahan penyakit tanaman yang divaksinasi lebih tinggi. Tanaman tomat yang divaksinasi dengan CARNA 5.1 dan CARNA 5.2 menghasilkan bobot buah yang lebih tinggi dan memproteksi tanaman terhadap superinfeksi TMV dan PVY (Gambar 3). Berdasarkan bobot buah yang lebih tinggi walupun keparahan penyakitnya juga lebih tinggi maka tipe ketahanan yang dihasilkan oleh vaksinasi CARNA 5.1 dan CARNA 5.2 terhadap PVY dan TMV adalah ketahanan interferens 
Tabel 2. Keparahan penyakit pada tanaman tomat yang divaksinasi CARNA 5.1 dan CARNA 5.2

\begin{tabular}{|c|c|c|c|c|}
\hline \multirow{2}{*}{ Perlakuan } & \multicolumn{4}{|c|}{ Keparahan penyakit (\%) } \\
\hline & $2 \mathrm{msi}$ & $3 \mathrm{msi}$ & $4 \mathrm{msi}$ & $5 \mathrm{msi}$ \\
\hline Vaks inasi CAR NA-5.1 & $4,99 b$ & $5,43 b$ & $6,35 b$ & $7,35 b$ \\
\hline Vaks inasi CAR NA-5.2 & $5,39 \mathrm{~b}$ & $5,72 b c$ & $6,38 b$ & $7,16 b$ \\
\hline Inokulasi dengan PVY, & $7,55 \mathrm{ef}$ & $7,63 \mathrm{ef}$ & $7,90 \mathrm{c}$ & $8,70 \mathrm{c}$ \\
\hline Inokulasi dengan TMV & 7,79f & $8,11 \mathrm{f}$ & $8,41 \mathrm{~d}$ & $8,59 \mathrm{c}$ \\
\hline Vaks inasi CAR NA-5.1 kemu dian diinokulasi PVY (30hst) & $6,68 \mathrm{~d}$ & $6,94 d$ & $7,58 \mathrm{c}$ & $8,00 \mathrm{bc}$ \\
\hline Vaks inasi CAR NA-5.2 kemu dian diinokulasi TMV(30hst) & 7,02de & $7,21 \mathrm{de}$ & $7,66 \mathrm{c}$ & $8,02 \mathrm{bc}$ \\
\hline Vaks inasi CAR NA-5.1 kemu dian diinokulasi TMV(30hst) & $6,77 \mathrm{~d}$ & $7,05 \mathrm{~d}$ & $7,71 \mathrm{c}$ & $7,90 \mathrm{bc}$ \\
\hline Vaks inasi CAR NA-5.2 kemu dian diinokulasi PVY (30hst) & $6,06 \mathrm{c}$ & $6,22 \mathrm{c}$ & $7,56 \mathrm{c}$ & $7,88 \mathrm{bc}$ \\
\hline Vaks inasi CAR NA-5.1 kemu dian diinokulasi PVY dan TMV(30hst) & 7,19def & 7,30de & $7,73 \mathrm{c}$ & $8,00 \mathrm{bc}$ \\
\hline Vaks inasi CAR NA-5.2 kemu dian diinokulasi PVY dan TMV (30hst) & $7,25 \mathrm{def}$ & $7,35 \mathrm{de}$ & $7,71 \mathrm{c}$ & $8,27 \mathrm{c}$ \\
\hline 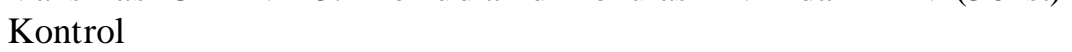 & $5,45 b$ & $5,92 \mathrm{bc}$ & $6,46 b$ & $7,38 b$ \\
\hline
\end{tabular}

Angka yang diikuti dengan huruf yang sama pada kolom yang sama tidak berbeda nyata menurut uji BNJ $(\mathrm{P}>0,05)$

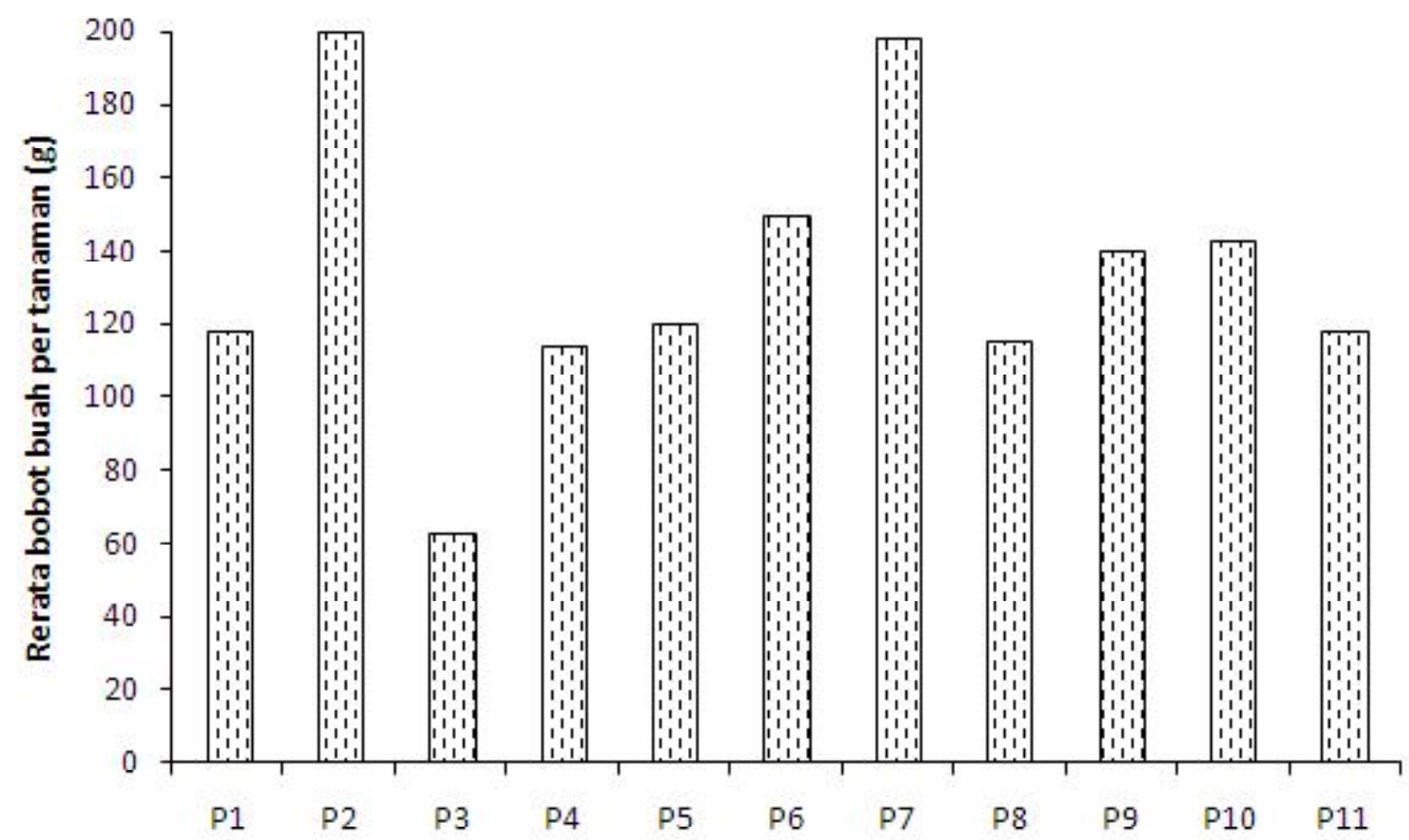

Perlakuan

Gambar 3. Rerata bobot buah pada masing-masing perlakuan. P1 = tanaman divaksinasi CARNA5.1, P2 = tanaman divaksinasi CARNA-5.2, P3 = tanaman diinokulasi dengan PVY, P4 = tanaman diinokulasi dengan TMV, P5 = tanaman divaksinasi dengan CARNA-5.1 sebelum diinokulasi PVY, P6 = tanaman divaksinasi dengan CARNA-5.2 sebelum diinokulasi TMV, P7 = tanaman divaksinasi dengan CARNA-5.1 sebelum diinokulasi TMV, P8 = tanaman divaksinasi dengan CARNA-5.2 sebelum diinokulasi PVY, $\mathrm{P} 9=$ tanaman divaksinasi dengan CARNA-5.1 kemudian diinokulasi dengan PVY dan TMV, P10 = tanaman divaksinasi dengan CARNA-5.1 kemudian diinokulasi dengan TMV dan PVY, dan P11 = tanaman tomat tidak diberi perlakuan inokulasi virus. 
(interferon) yang dapat meningkatkan toleransi tanaman terhadap virus yang tidak sejenis. Ketahanan melalui mekanisme interferon terjadi akibat penghambatan translokasi virus dalam sel tanaman akibat reaksi tanaman terhadap infeksi virus. Senyawa spesifik yang dihasilkan tanaman dalam menghambat infeksi virus sampai saat ini belum diketahui. Fenomena reaksi interferensi antara vaksin (CARNA 5.1 dan CARNA 5.2) dan TMV maupun PVY merupakan informasi baru yang perlu mendapat perhatian. Adanya indikasi reaksi interferensi itu memberi harapan juga bahwa vaksin itu dapat menginduksi ketahanan tanaman tomat dari superinfeksi virus yang secara taksonomi berbeda dengan strain lemah CMV yang membawa CARNA 5. Hal itu membuktikan bahwa kedua vaksin itu memenuhi syarat untuk dijadikan biokontrol penyakit virus pada tanaman tomat karena tidak bersinergi dengan virus lain yang juga menyerang tanaman tomat.

Fenomena proteksi silang yang ditunjukkan oleh vaksin (CARNA 5.1 dan CARNA 5.2) terhadap CMV strain ganas yang dominan di lapangan serta reaksi interferensi terhadap TMV dan PVY belum diketahui sehingga masih perlu dilakukan penelitian lanjutan di lapangan.

\section{SIMPULAN}

Vaksinasi CARNA 5.1 dan CARNA 5.2 efektif memproteksi tanaman tomat dari superinfeksi strain ganas CMV yang ditunjukan oleh keparahan penyakit yang lebih rendah, tinggi tanaman yang sama dengan tanaman sehat, dan hasil tanaman yang tinggi. Vaksin CARNA 5.1 dan CARNA 5.2 menimbulkan reaksi interferens dengan TMV dan PVY yang ditunjukkan oleh gejala penyakit yang ringan dan produksi tomat yang tidak berbeda dengan tanaman sehat.

\section{SANWACANA}

Penelitian ini didanai oleh Hibah Kempetisi A2 Program Studi Hama dan Penyakit Tumbuhan Jurusan Proteksi Tanaman Unila atas nama Penulis Utama. Ucapan terima kasih disampaikan kepada pengelola PHK A2 yang telah memberi dana dan Wagianto yang telah membantu dalam pelaksanaan penelitian ini.

\section{DAFTAR PUSTAKA}

Akin HM. 2005. Kepatogenan satelit RNA yang berasosiasi dengan Cucumber mosaic virus (CMV-SatRNA) pada tanaman cabai. J. HPT Tropika 5(1): 37-41.
Akin HM. 2006. Virologi Tumbuhan. Kanisius. Yogyakarta.

Alonso-Prados JL, Fraile A \& Garcia-Arenal F. 1997. Impact of cucumber mosaic virus and watermelon mosaic virus 2 infection on melon production in central Spain. J. Plant Pathol. 79: 131-134.

Crescenzi A, Barbarossa L, Cillo F, Di Franco A, Vovlas N, \& Gallitelli D. 1993. Role of Cucumber mosaic virus and its satellite RNA in the etiology of tomato fruit necrosis in Italy. Arch Virol 131: 321-333.

Gafny R, Wexler A, Mawassi M, Israeli Y \& Bar-Joseph M. 1996. Natural infection of banana by a satellite-containing strain of cucumber mosaic virus: nucleotide sequence of coat protein gene and the satellite RNA. Phytoparasitica 24:2956.

Gallitelli D. 1998. Present status of controlling cucumber mosaic virus. In: Khetarpal RK, Kagonezawa H, Hadidi A, Ed. Control of Plant Virus Diseases. APS Press, St. Paul, MN, USA.

Gallitelli D, Martelli GP, Gebre-Selassie \& Marchoux G. 1995. Progress in the biological and molecular studies of some important viruses of solanaceae in the Mediterranean. Acta Hortic 412: 503-514.

Herdt RW \& Steiner RA. 1995. Agricultural sustainability: concepts and conundrums. In: Barnett V, Payne R, Steiner R, Ed. Agricultural Sustainability: Economic, Environmental and Statistical Considerations. Wiley, Chichester, UK.

Hu, Chung-Chi, Hsu, Yau-Heiu \& Na-Sheng Lin. 2009. Satellite RNAs and satellite viruses of plants. Viruses.1(3): 1325-1350.

Jorda C, Alfaro A, Aranda MA, Moriones E \& GarciaArenal F. 1992. Epidemic of cucumber mosaic virus plus satellite RNA in tomatoes in Eastern Spain. Plant Dis. 76: 363-366.

Martin B, Collar JL, Tjallingii WF \& Fereres A. 1997. Intracellular ingestion and salivation by aphids may cause the acquisition and inoculation of nonpersistently transmitted plant viruses. J. Gen Virol 78: 2701-2705.

Palukaitis P, Roossink M, Dietzgen RG \& Francki RIB. 1992. Cucumber mosaic virus. Adv. Virus. Res. 41:281-348.

Perry KL, Zhang L, Shintaku MH \& Palukaitis P. 1994. Mapping determinants in cucumber mosaic virus 
for transmission by Aphis gossypii. Virology 205: 591-595.

Perry KL, Zhang L \& Palukaitis P. 1995. Differential transmission of cucumber mosaic virus by two aphids: mutation in the coat protein restore transmission by Aphis gossypii but not by Myzus persicae. Phytopathology 85:1143.

Summers CG, Stapleton JJ, Newton AS, Duncan RA \& Hart D. 1995. Comparison of srayable and film muches in delaying the onset of aphid-transmitted virus diseases in zucchini squash. Plant Dis. 79: 1126-1131.

Saputri A. 2005. Kepatogenan strain ganas CMV dan strain lemah CMV (Cucumber mosaic virus) yang berasosiasi dengan satelit RNA pada tanaman cabai merah. Skripsi. Fakultas Pertanian Unila, Bandar Lampung.
Sutarya R. 1989. Beberapa virus penting pada tanaman tomat di Kecamatan Lembang (Kabupaten Bandung). Bul. Penel. Hort. 72-79.

Uhan T.S \& Duriat AS. 1995. Pengaruh penggunaan vaksin CARNA-5, mulsa jerami, dan penyeprotan pestisida terhadap serangan hama dan penyakit cabai. Prosiding Seminar Ilmiah Komoditas Sayuran, Balitsa. 405-411.

Wagiyanto. 2005. Pengendalian cucumber mosaic virus pada cabai merah menggunakan strain lemah CMV yang berasosiasi dengan satelit RNA. Skripsi. Fakultas Pertanian.Universitas Lampung. Bandar Lampung.

Zulistiyorini, Y. 2005. Pengaruh infeksi gabungan antara CMV (cucumber mocaic virus) yang mengandung Sat-RNA dengan PVY dan TMV pada tanaman cabai besar (Capsicum annum L.). Skripsi. Fakultas Pertanian. Universitas Lampung. Bandar Lampung. 